\title{
Mitt liv er så lite
}

\author{
I juli i år møtte jeg to menn \\ jeg aldri vil glemme.
}

På et mottak i Midt-Norge ventet Ahmad som hadde sultet seg i 30 dager. Iraneren hadde fått endelig avslag på sin asylsøknad fra Utlendingsnemnda (UNE) før jul og advokatens omgjøringsbegjæring i januar var blitt avvist. Ahmad hadde noe han ville fortelle det norske samfunn. Og han ville be NOAS formidle sin avskjedshilsen.

Voksblek i ansiktet halvt lå Ahmad i stolen. Han snakket sakte, med lav stemme. Han ville heller dø i Norge enn i Iran. I Iran ventet døden, det var han overbevist om. Som tenåring opplevde Ahmad farens fremtidstro bli snudd til skuffelse og innbitt motstand mot Khomeinis prestestyre. Faren ble fengslet og torturert. Men han oppmuntret Ahmad til å fortsette kampen for frihet og demokrati.

Ahmad gikk med i en regimekritisk studentgruppe og ble utestengt fra videre medisinsk utdanning. Han ble fengslet og utsatt for grov voldsbruk. I 2008 fryktet han for sitt liv og flyktet til Norge. Mens han ventet på å få avgjort sin søknad om beskyttelse, fikk Ahmad entusiastiske hilsener fra faren i forkant av presidentvalget i juni 2009. Folkebevegelsen for ytringsfrihet og demokrati vant frem. Men valget ble kuppet, president Ahmadinejad erklært som valgvinner og fredelige protestdemonstrasjoner møtt med massedrap, fengsling og tortur. Faren ble fengslet. Moren var $\mathrm{d} ø \mathrm{~d}$ og hans søsken hadde flyktet til Italia og Canada. Etter brutal tortur døde faren på sykehus. Ahmad bar på skyld for at faren ble straffet for hans egen politiske aktivitet i eksil.

I Norge ble Ahmad ikke trodd. Han ble nektet beskyttelse. Uten avtale om tvangsretur av asylsøkere til Iran, kunne han ikke returneres. Ahmad forsøkte å opprettholde en mening i livet gjennom regimekritisk aktivitet og ved å ta ansvar for aktiviteter på mottaket. Men alt var tungt. I solidaritet sluttet han seg i juni til sultestreiken blant politiske fanger i iranske fengsler. En streik han valgte å fortsette på egenhånd, da aksjonen ble avsluttet i Iran.

- Mitt liv er så lite. Iran straffer det jeg tror på. De har drept min far. Min mor er død. Mine søsken har flyktet og fătt opphold i Italia og Canada. Her i Norge blir jeg ikke trodd. Prøver jeg å reise til Italia eller Canada, vil myndighetene der forholde seg til det norske avslaget. Jeg har passert 40. Jeg kan ikke studere eller arbeide i Norge. Norske myndigheter tror ikke på det som er mitt liv. Da har jeg ingen verdi. Ikke her. Ikke i Iran. Ingen steder. Jeg vet Norge arbeider for menneskerettigheter og demokrati. Men min verdi har jeg mistet her. Det er min sorg.

Dette var Ahmads budskap. Kunne jeg ta dette med meg tilbake til Oslo? Bare dersom vi kunne gjøre en avtale. Etter en lang samtale ble vi enige. Ahmad lovte å spise suppe og finne frem dokumentasjon på sin politiske aktivitet. På vår side skulle NOAS gå gjennom saken hans. Kan hende finner vi sammen frem til momenter som gir grunnlag for ny behandling i UNE.

Fredag ettermiddag 22. juli satt jeg med status så langt i Ahmads sak. Trykket fra bomben i regjeringskvartalet slo inn gjennom åpne vinduer i NOAS' kontor. Papirene løftet seg på pulten og braket ga gjenlyd i ørene. Ute på gaten var det fullt av glasskår. Mennesker i sjokk og mennesker med blødende sårskader beveget seg i alle retninger. Høyblokken var sterkt skadet og svart røyk steg opp fra regjeringskvartalet. Al-Qaida og en annen islamistisk gruppe tok raskt på seg ansvar. Min bekymring gikk til Ahmad og andre asylsøkere. Hvilke reaksjoner ville de få nå? Hvordan ville høstens valgkamp bli?

Så kom de første rapportene fra Utøya. Utover kvelden gikk vantro over i redsel og gru. I tidlige morgentimer ble ondskapen bekreftet. Gjennom bilder og tekst ble jeg presentert for en nordmann født samtidig som ayatolla Khomeini vendte tilbake til Iran. Med personlig frihet, fulle demokratiske rettigheter og bakgrunn fra Oslos vestkant, kunne han velge det livet han $\emptyset n$ nket. Hans valg var hat og kamp mot et flerkulturelt, likestilt og demokratisk Norge. Han tilla andre liten eller ingen verdi. Samtidig forstørret og forskjønnet han seg selv. Fysisk, gjennom trening, dop og operasjoner. Mentalt gjennom netts $\varnothing$ king og klipp og lim fra utvalgte, konspiratoriske kilder. I sitt eget verdensbilde vokste hans liv i rollen som ridder og Europas redningsmann. Bevisst bygde han ned sin identifisering med andre. De det var nødvendig å drepe, for å sikre medienes flomlys på ham selv. Hans liv var blitt for stort til å tillegge deres liv verdi.

Vi klarte ikke redde våre ungdommer fra drapsmannen på Utøya. Mitt håp er at Ahmad skal oppleve at hans menneskeverd blir sett og at hans liv er stort nok til å leve.

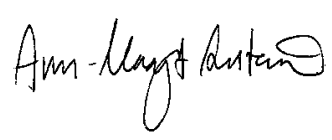

